\title{
ANALISIS PERBANDINGAN DAYA DUKUNG HASIL LOADING TEST PADA BORE PILE DIAMETER SATU METER TUNGGAL DENGAN METODE ELEMEN HINGGA MEMAKAI MODEL TANAH MOHR COULOMB PADA PROYEK CRYSTAL SQUARE MEDAN
}

\author{
Suhairiani $^{1}$, Roesyanto ${ }^{2}$, Rudi Iskandar ${ }^{3}$ \\ ${ }^{1}$ Dosen Pengajar Jurusan Pendidikan Teknik Bangunan, Fakultas Teknik UNIMED \\ 2,3Dosen Pengajar Studi Magister Teknik Sipil, Fakultas Teknik USU \\ (suhairiani@unimed.ac.id)
}

\begin{abstract}
ABSTRAK
Secara teknis untuk mengetahui daya dukung dari pondasi tiang biasanya dilakukan pengujian loading test, sehingga pada kasus ini dari 319 tiang bor yang ada, hanya 3 tiang yang dilakukan loading test. Penelitian ini bertujuan untuk memahami karakteristik tanah sebagai pemodelan dan menganalisis daya dukung tiang bor yang lain yang tidak dilakukan loading test pada proyek yang sama. Sehingga tidak perlu melakukan loading test lagi dengan alasan ekonomis. Hasil perhitungan daya dukung ultimate pondasi berdasarkan hasil penyelidikan tanah di lapangan sebesar 868 ton, Hasil pemodelan Elemen Hingga yang dikonsolidasi menurut ASTM sebesar 730 Ton, dan hasil pemodelan Elemen Hingga yang dikonsolidasi 7 hari 630 Ton, jika dibandingkan dengan hasil uji loading test di lapangan sebesar 791,5 ton, penurunan yang terjadi menggunakan pemodelan Elemen Hingga yang dikonsolidasikan menurut ASTM pada beban terbesar (830 Ton) adalah $24.81 \mathrm{~mm}$ dan penurunan yang terjadi menggunakan pemodelan Elemen Hingga yang dikonsolidasikan 7 hari pada beban terbesar (830 Ton) adalah $24.95 \mathrm{~mm}$, dan jika dibandingkan dengan hasil loading test di lapangan penurunan pada beban terbesar (830 Ton) yang terjadi sebesar $24.74 \mathrm{~mm}$. sementara penurunan yang diijinkan ASTM D1143/81 sebesar 1 inchi $(25.4 \mathrm{~mm})$, hal ini menjelaskan bahwa uji pembebanan vertikal yang dilakukan memenuhi syarat izin ASTM D1143/81.
\end{abstract}

\section{Kata Kunci : Bore Pile, Loading Test, Metode Elemen Hingga}

\section{Pendahuluan}

Loading test biasa disebut juga dengan uji pembebanan statik. Cara yang paling dapat diandalkan untuk menguji daya dukung pondasi tiang adalah dengan uji pembebanan statik. Interprestasi dari hasil benda uji pembebanan statik merupakan bagian yang cukup penting untuk mengetahui respon tiang pada selimut dan ujungnya serta besarnya daya dukung ultimitnya. Namun hal ini seringkali menjadi kendala dalam setiap pelaksanaanya untuk dilakukan penglodingan untuk semua tiang yang digunakan, karena pada setiap pelaksanaannya dibutuhkan biaya yang relatif mahal dan lamanya waktu pengerjaan sehingga tidak menguntungkan secara ekonomis.

Salah satu metode untuk menganalisis besarnya daya dukung aksial pondasi tiang bor pile adalah dengan menggunakan metode Elemen Hingga (finite element) yaitu dengan menggunakan program Plaxis, dimana menganalisinya dengan mempergunakan hasil data penyelidikan tanah di lapangan dan data hasil laboratorium kemudian hasil keseluruhannya dibandingkan dengan hasil uji pembebanan (Loading Test) yang dilakukan di lapangan dan peran metode Elemen Hingga disini untuk memahami karakteristik tanah sebagai pemodelan untuk menganalisis atau memprediksi daya dukung tiang bor yang lain yang tidak dilakukan loading test pada proyek yang sama.

Metode uji pembebanan ini disamping untuk menghitung daya dukung dan penurunan pondasi juga dapat melakukan simulasi konsolidasi waktu yang diperpanjang, yang berguna untuk melihat prilaku tiang bor dan prilaku tanah dimana untuk memperhitungkan tingkat keamanan bila bangunan tersebut mau ditingkatkan atau ditambah juga uji pembebanan ini dapat melihat kondisi ketidakpastian material tanah, material beton (tiang bor) di lapangan. 


\section{Tinjauan Pustaka}

2. 1 Pondasi Bore Pile

Pondasi bore pile adalah merupakan salah satu jenis pondasi yang kedalamannya lebih dari 2 meter dan biasa digunakan pada konstruksi bangunan-bangunan tinggi, sebab penggunaan pondasi bore pile antara lain: bore pile tunggal dapat digunakan pada tiang kelompok atau pile cap dengan kedalaman tiang dapat divariasikan, ketika proses pemboran dilakukan getaran tanah yang akan mengakibatkan kerusakan pada bangunan yang ada didekatnya dapat dicegah serta tidak ada suara yang ditimbulkan selama pelaksanaan pengeboran, dan pondasi bore pile mempunyai ketahanan yang tinggi terhadap beban lateral.

Pada pondasi bore pile jarak antara tiang bor di dalam kelompok tiang akan mempengaruhi kapasitas daya dukung kelompok tiang. Bila beberapa tiang dikelompokkan dengan jarak yang saling berdekatan maka tegangan tanah akibat gesekan tiang dengan tanah mempengaruhi daya dukung tiang yang lain. Jarak minimum antara dua tiang adalah: $S>2 \mathrm{D}$, dimana $S=$ jarak antara tiang dan $\mathrm{D}=$ diameter tiang dan daya dukung aksial suatu pondasi dalam pada umumnya terdiri atas dua bagian yaitu daya dukung akibat gesekan sepanjang tiang dan daya dukung ujung (dasar) tiang sebagaimana di formulasikan dalam bentuk persamaan sebagai berikut

$$
\mathrm{Q}_{\mathrm{u}}{ }^{-}=\mathrm{Q}_{\mathrm{p}}+\mathrm{Q}_{\mathrm{s}}
$$

$\mathrm{Q}_{\text {all }}=\mathrm{Q}_{\mathrm{u}} / \mathrm{SF}$

Dimana,

$\mathrm{Q}_{\mathrm{u}}=$ Daya dukung ultimit (Ton)

$\mathrm{Q}_{\text {all }}=$ Daya dukung izin tiang (Ton)

$\mathrm{Q}_{\mathrm{p}}=$ Daya dukung ujung tiang (Ton)

$\mathrm{Q}_{\mathrm{s}}=$ Daya dukung gesekan sepanjang tiang (Ton),

$\mathrm{SF}=$ Faktor keamanan

\subsection{Loading Test}

Tujuan dilakukan percobaan pembebanan vertikal (compressive loading test) terhadap pondasi tiang adalah untuk mengetahui hubungan antara beban dan penurunan pondasi akibat beban rencana, untuk menguji bawah pondasi tiang yang dilaksanakan mampu mendukung beban rencana dan membuktikan bahwa dalam pelaksanaan tidak terjadi kegagalan, dan untuk menentukan daya dukung ultimate nyata (real ultimate bearing capacity) sebagai kontrol dari hasil perhitungan berdasarkan formula statis maupun dinamis (Hardiyatmo, 2010).
Namun ada beberapa hal yang harus diperhatikan pada waktu pelaksanaan percobaan pembebanan vertikal (compressive loading test) adalah untuk tiang tiang beton "cast in place" percobaan dapat dilakukan setelah beton mengeras (28 hari) disamping mungkin ada persyaratan lainnya, untuk tiang tiang yang dipancang (pre cast) ada beberapa pendapat mengenai kapan tiang dapat di test. Menurut terzaghi, tiang tiang yang diletakkan diatas lapisan yang permeable (misal: pasir), maka percobaan sudah dapat dilakukan 3 (tiga) hari adalah pemancangan, pada tiang tiang yang dimasukkan dalam lapisan lanau dan lempung, maka percobaan ini hendaknya dilakukan setelah pemancangan berumur 1 (satu) bulan, hal lain yang perlu diperhatikan adalah berapa panjang tiang menonjol diatas tanah, pada prinsipnya penonjolan ini harus sependek mungkin untuk menghindari kemungkinan terjadinya tekuk, untuk loading test yang dilakukan didarat, maka sebanyak tinggi bagian yang menonjol ini tidak boleh lebih dari $1 \mathrm{~m}$, sedangkan loading test yang dilakukan ditengah sungai, dimana air cukup dalam, maka tiang dapat saja menonjol beberapa meter diatas dasar sungai (muka tanah) tetapi dengan catatan harus ada kontrol terhadap kemudian terjadinya tekuk.

Pada percobaan pembebanan pondasi tiang ini dilaksanakan berdasarkan standard pembebanan (loading) American Standard for testing material ASTM D. 1143-81 dengan metode slow maintened test. Pada penelitian ini menggunakan metode pembebanan langsung (Kentledge System) yaitu dengan menggunakan beban diatas pondasi tiang yang disusun sedemikian rupa dengan total berat yang lebih besar dari beban tes yang direncanakan. Dan pergerakan tiang dapat diukur dengan menggunakan satu set Dial Gauges yang terpasang pada kepala tiang. Toleransi pembacaan antara satu Dial Gauge lainnya adalah $1 \mathrm{~mm}$. Skematis metode pembebanan langsung (Kendeledge System) seperti pada Gambar 1. di bawah ini.

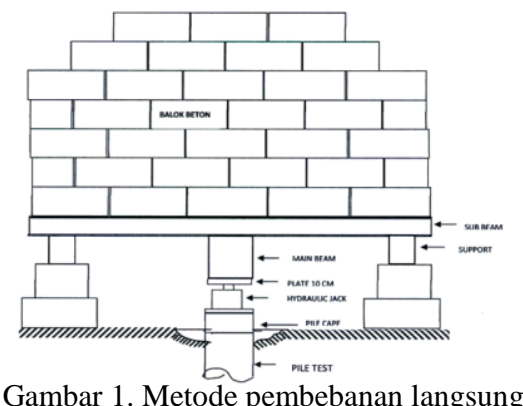

Gambar 1. Metode pembebanan langsung (kentledge system) 


\section{Analisis Perbandingan Daya Dukung Hasil Loading Test \\ Pada Bore Pile Diameter Satu Meter Tunggal Dengan Metode Elemen Hingga Memakai Model Tanah Mohr Coulomb Pada Proyek Crystal Square Medan}

\subsection{Interpretation Method}

\subsubsection{Metoda Davisson (1973)}

Jika Kurva beban penurunan telah diperoleh dari uji beban tiang, dengan metode Davisson dapat diestimasi besarnya beban ultimit tiang. Pada jenis tanah lempung lunak, beban yang menyebabkan keruntuhan tiang terjadi pada beban yang konstan dengan penurunan yang berlebihan. Akan tetapi, bila tiang pada pasir tanah tanah campuran atau lempung kaku, penentuan titik keruntuhan tiang pada kurva beban - penurunan menjadi agak sulit (Hardiyatmo, 2010).

Penentuan $\mathrm{Qu}$ dengan metode Davisson dapat dilihat pada Gambar 2 di bawah ini.

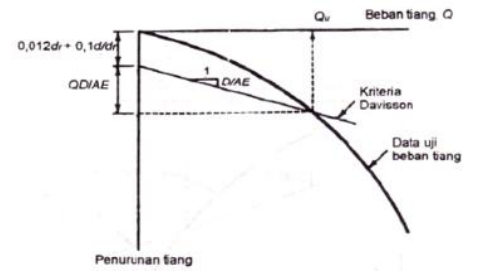

Gambar 3. Penentuan Qu dengan Metode Davisson (1973)

Davisson (1973) mengusulkan cara yang telah banyak dipakai saat ini. Cara ini didefinisikan kapasitas dukung ultimit tiang pada penurunan tiang sebesar (lihat Gambar 2)

$$
Q_{U l t}=0.012 d_{r}+0.1 \frac{d}{d_{r}}+\frac{Q D}{A E}
$$

Dimana,

$\mathrm{d}=$ Diameter $/$ lebar Tiang $(\mathrm{mm})$

$\mathrm{d}_{\mathrm{r}}=1 \mathrm{ft}=300 \mathrm{~mm}$

$\mathrm{Q}=$ Beban yang bekerja Pada Tiang

$\mathrm{D}=$ Kedalaman Tiang $(\mathrm{mm})$

$\mathrm{A}=$ Luas Penampang Tiang $\left(\mathrm{mm}^{2}\right)$

$\mathrm{E}=$ Modulus Elastis Tiang (Mpa)

$=200000 \mathrm{Mpa}$, untuk Baja

$=15200$ or $\left(\mathrm{f}_{\mathrm{c}}^{\prime} / \sigma_{\mathrm{r}}\right)^{0.5}$, dan

$\sigma_{\mathrm{r}}=0.1 \mathrm{Mpa}=100 \mathrm{Kpa}$

\subsubsection{Metode Mazurkiewicz (1972)}

Metode ini diasumsikan bahwa dengan kapasitas tahanan terbesar (ultimate) akan didapatkan dari beban yang berpotongan, diantaranya beban yang searah sumbu tiang untuk dihubungkan beban dengan titik-titik dari posisi garis terhadap sudut $45^{\circ}$ pada beban sumbu yang berbatasan dengan beban (Prakash dan Sharma, 1990). Prosedur untuk menetukan beban ultimate menggunakan metode ini adalah sebagai berikut:

- Plot Kurva Beban - Penurunan

- Pilih sejumlah penurunan dan gambarkan garis verikal yang memotong kurva.
Kemudian gambar garis horizontal dari titik perpotongan ini pada kurva sampai memotong sumbu beban.

- Dari perpotongan masing masing kurva, gambar garis $45^{\circ}$ sampai memotong garis beban selanjutnya.

- Perpotongan ini jatuh kira kira pada garis lurus. Titik yang didapat oleh perpotongan dari perpanjangan garis ini pada sumbu vertical (beban) adalah beban ultimate.

Metoda ini mengasumsikan bahwa kurva beban - penurunan berupa parabolic. Nilai beban keruntuhan yang didapat dari metoda ini seharusnya mendekati 80\% dari kenyataan. Hal ini dapat diperlihatkan Gambar 3 di bawah ini.



Gambar 3. Grafik hubungan beban dengan penurunan metode Mazurkiewicz

\subsection{Penurunan Tiang Tunggal}

Menurut Poulus dan Davis (1980) penurunan jangka panjang untuk pondasi tiang tunggal tidak perlu ditinjau karena penurunan tiang akibat konsolidasi dari tanah relatif kecil. Hal ini disebabkan karena pondasi tiang direncanakan terhada kuat dukung ujung dan kuat dukung friksinya atau penjumlahan dari keduanya (Hardiyatmo, 2010).

Perkiraan penurunan tiang tunggal dapat dihitung berdasarkan:

a. Untuk tiang apung atau tiang friksi

$$
\begin{aligned}
& S=\frac{Q I}{E_{S} d} \\
& I=I_{o} R_{k} R_{h} R_{\mu}
\end{aligned}
$$

b. Untuk Tiang Dukung Ujung

$$
\begin{aligned}
& S=\frac{Q I}{E_{s} d} \\
& I=I_{o} R_{k} R_{h} R_{\mu}
\end{aligned}
$$

Dimana,

$\mathrm{S}=$ Penurunan untuk tiang tunggal $(\mathrm{mm})$

$\mathrm{Q}=$ Beban yang bekerja (ton)

$\mathrm{I}_{\mathrm{o}}=$ Faktor pengaruh penurunan untuk tiang yang tidak mudah mampat (Gambar 4)

$\mathrm{R}_{\mathrm{k}}=$ Faktor koreksi kemudah mampatan tiang (Gambar 5)

$\mathrm{R}_{\mathrm{h}}=$ Faktor koreksi untuk ketebalan lapisan yang terletak pada tanah keras (Gambar 6)

$\mathrm{R}_{\mu}=$ Faktor koreksi angka Poisson $\mu$ (Gambar 7) 
$\mathrm{R}_{\mathrm{b}}=$ Faktor koreksi untuk kekakuan lapisanpendukung (Gambar 8)

$\mathrm{h}=$ Kedalaman total lapisan tanah dari ujung tiang ke muka tanah ( $\mathrm{mm})$, dan

$\mathrm{D}=$ Diameter tiang $(\mathrm{mm})$
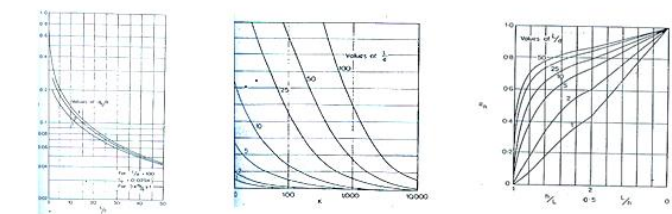

Gambar 4. Faktor Penununan Iem Gambar 5, Koreksi Kompresi, $\mathbb{R}_{k}$ Gambar 6. Koreksi Kedalaman, $\mathbb{R}_{k}$
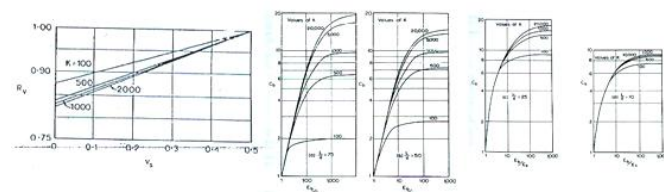

Gambar J $_{\mu}$ Koreksi Angka Poison, $R_{\mu} \quad$ Gambar 8. Koreksi kekakuan lapisan pendukung, $R_{b}$ Poulus dan Davi

Pada Gambar 4, 5, 6, 7, dan 8, K adalah suatu ukuran kompresibilitas relatif dari tiang dan tanah yang dinyatakan oleh persamaan:

$$
\begin{aligned}
K & =\frac{E_{p} R_{A}}{E_{S}} \\
R_{A} & =\frac{A_{p}}{1 / 4 \pi d^{2}}
\end{aligned}
$$

$\mathrm{K}=$ Faktor kekakuan tiang.

$\mathrm{E}_{\mathrm{p}}=$ Modulus elastisitas dari bahan tiang (Mpa), dan $\mathrm{E}_{\mathrm{s}}=$ Modulus elastisitas tanah disekitar tiang (Mpa).

\subsection{Pentransferan Beban}

Berdasarkan cara penyaluran bebannya

ketanah, pondasi tiang dibedakan yaitu:

- Pondasi tiang dengan tahanan ujung (end bearing pile)

Tiang ini akan meneruskan beban melalui tahanan ujung tiang ke lapisan tanah pendukung. Umumnya tiang dukung ujung berada dalam zona tanah yang lunak yang berada diatas tanah keras, dan suatu tiang yang dibebani oleh suatu beban maka akan tejadi adanya gaya tahanan ujung (end bearing), gaya tahanan ujung ini akan bekerja bila displacement yang terjadi masih diatas 0.4 $\%$ diameter pile dan dalam ambang batas $6 \%$ dari diameter pile. Dan bila displacement yang terjadi pada suatu tiang masih berada dalam $0.4 \%$ dari diameter pile, maka end bearing belum terjadi atau belum tercapai. Seperti yang terlihat pada skema Gambar 9 dibawah ini.

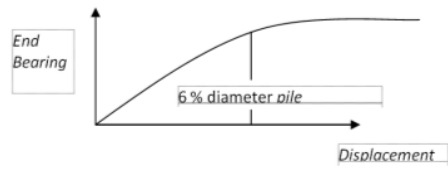

Gambar 9. Skema kurva transfer beban endbearing
- Pondasi tiang dengan tahanan gesek (friction pile)

Jenis tiang ini akan meneruskan beban ke tanah melalui gesekan antara tiang dengan tanah di sekelilingnya. Bila butiran tanah sangat halus tidak menyebabkan tanah di antara tiang - tiang menjadi padat, sedangkan bila butiran tanah kasar maka tanah di antara tiang akan semakin padat, dan gaya gesekan ini akan bekerja bila displacement yang terjadi masih dalam ambang batas $0.4 \%$ dari diameter pile. Seperti yang terlihat pada skema Gambar 10 dibawah ini.



Gambar 10. Skema kurva transfer beban friction

\subsection{Elemen Hingga Program Plaxis}

FEM untuk geoteknik berbeda dengan yang lain pada program tertentu jenis elemennya dipisahkan antara elemen linier untuk respon tekanan air pori dan kwadratic untuk respon tegangan-regangan pada butiran tanah dan ada juga yang menyamakannya. Analisa dengan metode Elemen Hingga pada rekayasa geoteknik umumnya merupakan analisa yang kompleks, sehingga penyelesaian dengan perhitungan manual dan metode eksak akan sangat sulit dilakukan. Untuk itu penggunaan salah satu program komputer yang umum dipergunakan dalam komputasi rekayasa geoteknik adalah Plaxis.

Plaxis adalah program Elemen Hingga (finite element program) untuk aplikasi geoteknik yang mana model model tanah digunakan untuk mensimulasikan prilaku tanah. Sebelum melakukan perhitungan dengan program Elemen Hingga terlebih dahulu harus dipahami teori tentang pemodelan tanah yang akan dipilih. Kesalahan dalam pemilihan model tanah dapat mengakibatkan kekeliruan terhadap hasil perhitungan yang diperoleh. parameter model yang dapat dipergunakan adalah Plane Strain dan Axisymmetris. Pada penelitian ini parameter model yang digunakan adalah Axisymmetris, dimana model Axisymmetris dipergunakan untuk struktur sirkular dengan tanah arah radial dianggap seragam, dimana deformasi dan tegangan diasumsikan sama di semua arah radial. Pada model ini sumbu $x$ merepresentasikan radius dan sumbu y disamakan dengan sumbu simetri 


\section{Analisis Perbandingan Daya Dukung Hasil Loading Test \\ Pada Bore Pile Diameter Satu Meter Tunggal Dengan Metode Elemen Hingga Memakai Model Tanah Mohr Coulomb Pada Proyek Crystal Square Medan}

aksial pemodelan. Ilustrasi permasalahan Axisymmetris tersebut dapat dilihat pada Gambar 11 dibawah ini.

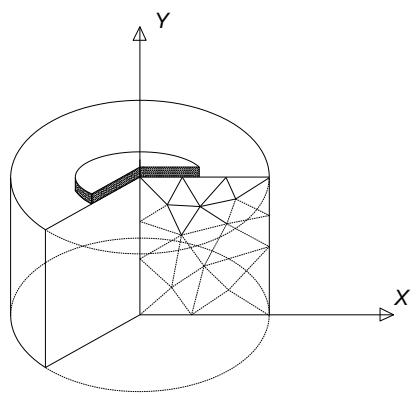

Gambar 11. Gambar ilustrasi permasalahan Axisymmetris

Untuk menghitung korelasi beban vertikal batas (ultimit) dengan displacement yang terjadi pada suatu tiang bor beton dengan Elemen Hingga model tanah yang digunakan adalah model Mohr-Coulomb dengan analisis Axisymetric. Hasil permodelan Elemen Hingga dengan program Plaxis dibandingkan dengan pengujian lapangan (loading test).

Pada model Mohr Coulomb mengasumsikan prilaku tanah bersifat plastis sempurna dengan menetapkan suatu nilai tegangan batas dimana pada titik tersebut tegangan tidak lagi dipengarui oleh regangan. Input parameter meliputi Modulus young $\left(\mathrm{E}_{\mathrm{s}}\right)$, Poison rasio (v), Kohesi (c), Sudut geser (Ø) dan Sudut Dilatansi $(\Psi)$.

Pada Plaxis versi 8.2 yang dipergunakan terdapat dua opsi Elemen Hingga yaitu elemen yang memiliki 6 titik nodal atau elemen yang memiliki 15 titik nodal, dimana tiap nodal memiliki 2 degree of freedom (DOF), dan disini penulis menggunakan 15 titik nodal dimana untuk memperoleh perhitungan yang lebih akurat, akan tetapi akan menghasilkan persamaan numerik yang lebih kompleks.

\section{Metodologi Penelitian}

\subsection{Tinjauan Daerah Penelitian}

Proyek Crystal Square adalah
pembangunan
Bangunan Hotel dan Perkantoran berlantai 16 yang terdiri dari 13 lantai bangunan dan 3 lantai basement. Ketingggian bangunan adalah 65 meter serta kedalaman basement adalah 9 meter dari muka tanah.

Proyek Crystal Square terletak di jalan Imam bonjol No. 6. Medan. Di daerah sekitar lokasi proyek terdapat beberapa bangunan penting seperti Gedung Bank Mandiri, Rumah Sakit Malahayati, Gedung HSBC, Kantor Pengadilan
Tinggi dan bangunan bangunan lain milik pemerintah maupun milik masyarakat.

Untuk meneruskan/mentransfer beban dari bagian struktur atas dan bangunan atas (upper structures/super structures) kelapisan tanah dibawahnya hingga mencapai daya dukung yang diinginkan, maka diperlukan suatu bagian konstruksi bangunan bawah (sub structures) yang disebut dengan pondasi, dalam hal ini direncanakan menggunakan pondasi tiang bor.

Dalam proyek ini dipergunakan pondasi tiang bor dengan panjang bore pile 23,3 meter, berdiameter satu meter, dengan beban kerja loading 415 ton dan beban maksimum loading test 830 ton, dengan metode pembebanan Kentledge System (beban langsung) berdasarkan prosedur Slow Maintened Loading dengan beracuan ASTM D 1143-81 berdasarkan jenis pembebanan static axial compressive loading.

Data yang diperoleh pada studi kasus ini adalah data boring tanah asli sebanyak 1 titik, data Sondir tanah asli sebanyak 4 titik, dan data loading test sebanyak 2 titik tiang bore pile. Dari data boring dan sondir yang ada diambil hanya sebanyak 1 titik yang paling dekat dengan tiang bore yang diadakan loading test.

\subsection{Studi kasus: Loading Test bore Pile Diameter Satu Tunggal Di Crystal Square} Medan

Pemodelan pada studi ini dilakukan dengan bantuan program Plaxis dimana secara garis besar Pemodelan geometrik yang dilakukan terhadap tanah dan tiang adalah model Axysimetris yaitu model tanah yang memperhitungkan (menggambarkan) seperempat dari kondisi sebenarnya, dengan pemilihan model tanah, dimana model tanah yang dipilih adalah model Mohr Coulomb. Kemudian setelah, memodelkan geometrinya dilakukan pemasukan-parameter parameter tanah yang didapat dari hasil penyelidikan tanah kedalam program Plaxis. Gambar 11 menunjukkan pemodelan Elemen Hingga tanah di modelkan dalam 11 lapisan tanah dengan 1 pemodelan tiang dengan pemberian beban secara bertahap, pemodelan ini, di modelkan mengikuti parameter tanah yang ada di lapangan. Data masukan yang digunakan pada pemodelan Elemen Hingga adalah pemasukan data dilakukan dengan proses pembentukan model geometrik, dimana struktur tanah yang hendak dihitung digambar terlebih dahulu, dengan lebar dimabil $20 \mathrm{D}(\mathrm{D}=$ diameter bore pile), kemudian pemilihan model 
material properties yang digunakan, dimana pemilhan tersebut adalah jenis tiang yang digunakan, penggunaan jenis beban yang digunakan, dan pemasukan elemen interface, memasukkan nilai parameter, dimana nilai pemasukan parameter, pemilihan mesh serta penentuan kondisi batas termasuk muka air tanah sebesar $2.5 \mathrm{~m}$ dari permukaan tanah. Seperti yang terlihat pada Gambar 3.1 dibawah ini:

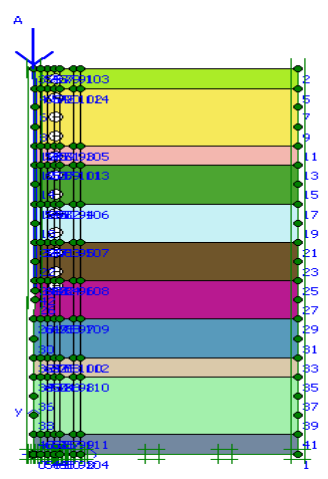

Gambar 11. Pemodelan lapisan tanah dan tiang

Pada pemodelan Elemen Hingga, terdapat 2 pembagian titik nodal, dimana penggunaan 6 titik nodal dan 15 titik nodal, bila kita menggunakan 6 nodal, maka hasil penurunan yang didapat belum mendekati dengan keadaan di lapangan, sehingga penulis memakai pengunaan 15 titik nodal.

Kemudian setelah selesai pembentukan mesh, tahap berikutnya penentuan initial condition yang meliputi penentuan muka air tanah, initial stress, kemudian dilakukan perhitungan dengan terlebih dahulu memasukkan data data pembebanan.

\section{Pembahasan}

\subsection{Perumusan Analitis}

Dari perumusan analitis maka untuk daya dukung ultimit direncanakan sebesar 830 ton, hasil data penyelidikan tanah (pengujian SPT, sondir serta hasil laborotorium) serta uji pembebanan tiang di lokasi Crystal Square, untuk kedalaman tiang bor sebesar 23.3 meter:

Tabel 1.: Daya dukung ultimit data penyelidikan tanah

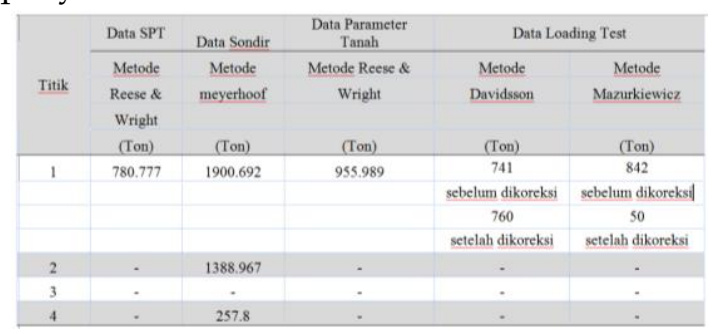

dari hasil penyelidikan tanah, dimana hasil pengujian SPT, Sondir serta hasil Laborotorium diatas didapat hasil daya dukung Sondir lebih besar daripada hasil pengujian SPT dan hasil Laborotorium. serta berdasarkan hasil daya dukung loading test nilai daya dukung ultimit untuk 2 metode diatas nilainya hampir mendekati antara yang menggunakan metode Davisson maupun yang menggunakan metode Mazurkiewicz

\subsection{Pentransferan Beban}

Dari skema Gambar (10) dapat dibuat kurva transfer beban friksi seperti pada Gambar 12 di bawah ini:

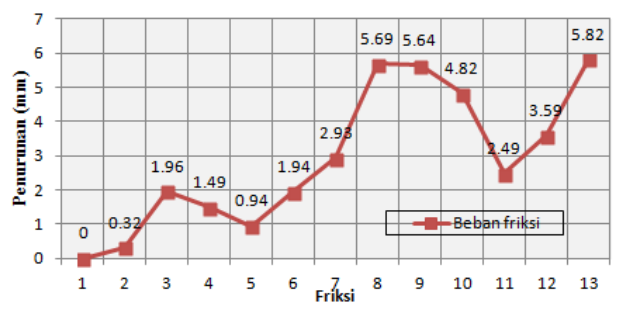

Gambar 12. Kurva transfer beban friksi

Pada Gambar 12 menggambarkan gaya gesekan ini akan bekerja bila displacement yang terjadi masih dalam ambang batas $0.4 \%$ dari diameter pile (skema Gambar 10) atau displacement yang terjadi sebesar $4 \mathrm{~mm}$.

Pada gedung Crystal Square, pentransferan beban friksi terjadi atau dimulai dari pemberian beban pertama 0 (nol) ton sampai beban 415 ton. Atau terjadi pada saat cycle ke-3 dengan beban $100 \%$ dari working load. Penurunan tersebut terjadi ditentukan oleh perlawanan gesek antara dinding tiang dan tanah disekitarnya dimana tahanan gesek tersebut juga dipengarui oleh pengaruh konsolidasi lapisan tanah. Dan tiang pada kondisi ini masih mengalami keadaan deformasi elastis.

Dan dari skema Gambar (9) diperoleh kurva transfer beban tahanan ujung seperti pada Gambar 13 dibawah ini:



Gambar 13 Kurva transfer beban tahanan ujung 


\section{Analisis Perbandingan Daya Dukung Hasil Loading Test \\ Pada Bore Pile Diameter Satu Meter Tunggal Dengan Metode Elemen Hingga Memakai Model Tanah Mohr Coulomb Pada Proyek Crystal Square Medan}

Pada Gambar 13 menggambarkan kurva gaya tahanan ujung yang terjadi pada suatu tiang. Gaya tahanan ujung ini akan bekerja bila displacement yang terjadi dalam ambang batas 6 $\%$ dari diameter pile (Skema Gambar 9) atau displacement yang terjadi sebesar $60 \mathrm{~mm}$. Pentransferan beban tahanan ujng ini terjadi atau dimulai dari pemberian beban pertama 0 (nol) ton sampai beban maksimum atau 830 ton. Pada pentransferan beban tahanan ujung ini, umumnya tiang berada dalam zona tanah yang lunak yang berada diatas tanah keras. Tiang ini dipancang atau di bor sampai mencapai batuan dasar atau lapisan keras lain agar tidak mengakibatkan penurunan berlebihan, dan juga kapasitas tiang sepenuhnya ditentukan dari tahanan dukung lapisan keras yang berada dibawah ujung tiang. Dan tiang pada kondisi ini, sudah dalam keadaan plastis.

Dan pada tiang bor proyek Crystal Square ini sudah terjadi pentransferan beban, baik itu beban friction maupun beban end bearing.

\subsection{Model lapisan}

Tabel 2 menunjukkan parameter - parameter yang digunakan dalam analisis pada program Plaxis

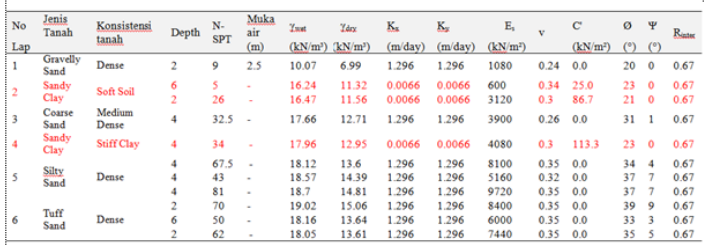

\subsection{Analisis Perbandingan Hasil Loading Test}

Jika hubungan antara beban dengan penurunan hasil loading test dibandingkan dengan hasil hubungan antara beban dengan penurunan hasil pemodelan Elemen Hingga (ASTM) dengan yang dikonsolidasi 7 hari akan menampilkan seperti Gambar 14 dibawah ini:

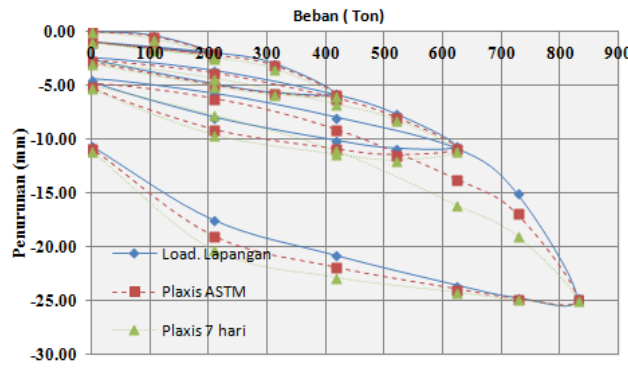

Gambar 13. Grafik Hubungan Beban dan

Penurunan antara Loading Test di lapangan dengan Elemen Hingga ASTM dengan Elemen Hingga yang dikonsolidasikan 7 hari
Dari Gambar 13 dapat kita lihat bahwa hubungan beban dan penurunan antara loading test di lapangan dengan Elemen Hingga ASTM dengan Elemen Hingga yang dikonsolidasikan 7 hari dapat dianalisa:

- Semakin besar beban yang diberikan, maka semakin besar penurunan yang terjadi.

- Semakin Lama waktu yang diberikan atau semakin lama konsolidasi, maka penurunan yang terjadi juga semakin besar dan ini terjadi pada pemodelan Elemen hingga yang dikonsolidasi 7 hari.

Dari Grafik 13 dapat dilihat bahwa penurunan permananen (rebound plastis) yang terbesar terjadi pada saat pemberian konsolidasi 7 hari, ini bisa disebabkan karena waktu yang diberikan lebih lama dari waktu yang ditetapkan atau sesuai ASTM D1143/81.

Penggunaan nilai korelasi modulus elastisitas yang di input pada pemodelan tanah juga sangat mempengarui pendekatan hasil penurunan dengan penurunan yang dihasilkan di lapangan.

\section{Kesimpulan dan Saran}

\subsection{Kesimpulan}

Kesimpulan dibuat berdasarkan dari diskusi tentang hasil pemodelan Elemen Hingga yang menggunakan model Mohr Coulomb untuk konsolidasi 7 hari dengan pemodelan Elemen Hingga yang menggunakan model Mohr Coulomb ASTM yang dihasilkan dari program Plaxis, beberapa kesimpulan yang dapar dipaparkan dari analisa tersebut antara lain:

1. Daya Dukung Ultimit dari Output Pemodelan Elemen Hingga model Mohr Coulomb konsolidasi 7 hari (630 ton), lebih kecil dari hasil Pemodelan Elemen Hingga model Mohr Coulomb ASTM (730 ton) dan hasil dari Loading Test (791,5 ton).

2. Dari Hasil Penyelidikan tanah, dimana hasil Pengujian SPT, Sondir serta Hasil Laborotorium diatas didapat hasil Daya dukung Sondir (1182,48 Ton) lebih besar daripada Hasil Pengujian SPT $(780,777$ Ton) dan Hasil laborotorium (955,989 Ton). Serta berdasarkan Hasil daya dukung Loading Test Nilai daya Dukung Ultimit untuk 2 metode nilainya hampir mendekati antara yang menggunakan metode Davisson (741 Ton) maupun yang menggunakan metode Mazurkiewicz (842 Ton).

3. Perbandingan Hasil Perhitungan antara Loading Test dengan hasil perhitungan pemodelan Elemen Hingga: 
- Penurunan permanen di kepala tiang dari pemodelan Elemen Hingga model Mohr Coulomb konsolidasi 7 hari (11.55 $\mathrm{mm})$, lebih besar dari hasil pemodelan Elemen Hingga model Mohr Coulomb ASTM (11.03 mm) dan hasil dari Loading Test $(10.59 \mathrm{~mm})$, hal ini bisa dipengarui oleh waktu yang diberikan lebih lama dari waktu yang ditetapkan atau sesuai ASTM D1143/81, dan juga bisa dipengarui oleh keadaan tanah pada ujung tiang, dimana pada ujung tiang bor terdapat lapisan tanah pasir yang menyebabkan tingkat elastisitas yang terjadi menjadi kecil.

- Rebound elastis Maksimum dari Pemodelan Elemen Hingga model Mohr Coulomb konsolidasi 7 hari $(13.4 \mathrm{~mm})$, lebih kecil dari hasil Pemodelan Elemen Hingga model Mohr Coulomb ASTM (13.78 $\mathrm{mm})$ dan hasil dari Loading Test (14.15 mm).

- Penurunan maksimum saat beban maksimum dari pemodelan Elemen Hingga model Mohr Coulomb konsolidasi 7 hari $(24.95 \mathrm{~mm})$, lebih besar dari hasil Pemodelan Elemen Hingga model Mohr Coulomb ASTM ( $24.81 \mathrm{~mm}$ ) dan hasil dari Loading Test (24.74 $\mathrm{mm})$, karena semakin besar beban dan waktu yang diberikan, semakin lama waktu dan konsolidasi yang terjadi.

4. Menurut ASTM D-1143-81 prosedur Standard Loading Test untuk pondasi adalah $200 \%$ dari angka keamanan penurunan diambil $25.4 \mathrm{~mm}$. Dan pada kasus Crystal Square tiang bor dalam keadaan Aman.

5. Jumlah Tiang Bor yang terpasang di Proyek Crystal Square ini berjumlah 319 tiang dan hanya 3 tiang yang melakukan uji pembebanan, dimana 2 tiang diadakan uji pembebanan vertikal (compressive Loading Test) dan 1 tiang melakukan uji pembebanan horizontal (lateral Loading Test), ini berarti hanya $0.94 \%$ dari tiang yang di loading.Ddan penglodingan di Proyek Crystal Square dilakukan pada umur beton 28 hari.

\subsection{Saran}

Pada pemodelan Elemen Hingga yang menggunakan model Mohr Coulomb untuk konsolidasi 7 hari dengan pemodelan Elemen Hingga yang menggunakan model Mohr coulomb ASTM diharapkan adanya penyelidikan tanah yang teliti serta korelasi parameter yang digunakan dalam pemodelan agar diperoleh data yang sesuai dengan kondisi tanah yang sebenarnya.

\section{Daftar Pustaka}

American Standart Test Method, 2010, Annual Book of ASTM Standart, Section Four Construction, Barr Harbor.

Bowles, J.E., 1998, Analisis dan Desain Pondasi, Jilid 2 Edisi Keempat, Erlangga, Jakarta

Das, B.M., 1999, Principle of Foundation Engineering, $4^{\text {nd }}$ Edition, PWS - KENT Publishing Company, Boston.

Napitu, E., 2007, Kajian Daya Dukung Dan Penurunan Tiang Pancang Beton Berdasarkan Data Lapangan, Laborotorium Dan Menggunakan Program Plaxis di Sepanjang Sungai Percut Sematera Tesis, Pascasarjana Universitas Sumatera Utara, Medan.

Hardyatmo, H.C., 2010, Teknik Pondasi, jilid 1 dan 2, Penerbit Gramedia, Jakarta.

Hardyatmo, H.C., 2010, Mekanika Tanah, jilid 1 dan 2, Penerbit Gramedia, Jakarta.

Logan, D.L., 1992, A First Course In The Finite Element Method, 2nd Edition, PWSKENT Publishing Company, Boston.

Manual PLAXIS Version 8,2

Poulos, H.G., \& Davis, E.H., 1940, Pile Foundation Analysis And Design, John Willey dan Sons, Sydney.

Prakash, S.H., \& Sharma, D., 1990, Pile Foundations In Engineering Practice, John Willey dan Sons, Inc. Canada.

Iskandar, R., 2002, Beberapa Kendala Teori Perhitungan Daya Dukung Aksial Pondasi Dalam, USU, Sumatra Utara.

Sinaga, S., 2009, Analisa Daya Dukung Dan Penurunan Bore Pile Tunggal Dengan Menggunakan Model Tanah Mohr Coulomb Pada Proyek City Hall Town Square, Tesis, Sekolah Pascasarjana Universitas Sumatera Utara, Medan.

Sirait, K., 2005, Laporan Percobaan Pembebanan Vertikal Proyek Pembangunan Hotel Dan Perkantoran Crystal Square, PT .Perintis Pondasi Teknotama, Medan.

Sosrodarsono, S., 1984, Mekanika Tanah dan Teknik Pondasi, Penerbit PT. Pradnya Paramita, Jakarta. 
Thomlison, M.J., 1977, Pile Design and Construction Practice, Viewpoint Publications.

Wesley, L.D., 1977, Mekanika Tanah, Penerbit Pekerjaan Umum, Jakarta. 